\title{
Kinetika Reaksi Transesterifikasi Minyak Kedelai Menjadi Biodiesel Menggunakan Katalis Padat Ramah Lingkungan $\mathrm{K}_{2} \mathrm{O} / \mathrm{CaO}-\mathrm{ZnO}$
}

\author{
Windarto Aribowo, Amin Nugroho, I. Istadi* \\ Departemen Teknik Kimia, Fakultas Teknik, Universitas Diponegoro \\ Jl. Prof. Soedarto, S.H., Kampus Undip Tembalang, Semarang, Indonesia 50275
}

\begin{abstract}
Abstrak
Katalis padat yang ramah lingkungan $\mathrm{K}_{2} \mathrm{O} / \mathrm{CaO}-\mathrm{ZnO}$ memiliki keunggulan untuk proses reaksi transesterifikasi meliputi sifat basa heterogen aktif, kelarutan rendah, kekuatan mekanik yang baik, dan dapat digunakan kembali. Penelitian ini bertujuan untuk mengkaji kinetika reaksi transesterifikasi minyak kedelai menjadi biodiesel menggunakan katalis padat $\mathrm{K}_{2} \mathrm{O} / \mathrm{CaO}-\mathrm{ZnO}$ untuk mendapatkan model persamaan laju reaksi heterogen. Kajian meliputi: prediksi mekanisme yang sesuai dengan data eksperimen melalui analisis ketergantungan perubahan laju reaksi terhadap perubahan masing-masing reaktan dan perumusan persamaan akhir laju reaksi. Persamaan laju reaksi yang dihasilkan dapat dipakai untuk perancangan reaktor. Hasil kajian menunjukkan bahwa mekanisme reaksi yang terjadi mengikuti mekanisme Eley-Rideal, dimana metanol yang teradsorpsi pada permukaan katalis bereaksi dengan trigliserida (minyak kedelai) pada fase cairnya menghasilkan biodiesel (fatty acid methyl ester) dan gliserol. Persamaan laju reaksi yang diperoleh digunakan dalam perancangan reaktor sehingga hubungan antara berat katalis yang dibutuhkan dengan konversi trigliserida menjadi biodiesel dan perhitungan volume reaktor yang dibutuhkan dapat dilakukan.
\end{abstract}

Kata kunci: kinetika reaksi transesterifikasi; minyak kedelai; biodiesel; katalis $\mathrm{K}_{2} \mathrm{O} / \mathrm{CaO}-\mathrm{ZnO}$; reaktor CSTR terfluidisasi

\begin{abstract}
[Title: Kinetics of Soybean Oil Transesterification Reaction to Biodiesel Using $\mathrm{K}_{2} \mathrm{O} / \mathrm{CaO}-\mathrm{ZnO}$ Solid Catalyst] The environmentally friendly $\mathrm{K}_{2} \mathrm{O} / \mathrm{CaO}-\mathrm{ZnO}$ solid catalyst has advantages for transesterification reaction including active heterogeneous base properties, low solubility, good mechanical strength, and reusable. This study aims to examine the kinetic reaction of transesterification of soybean oil to biodiesel using a solid catalyst $\mathrm{K}_{2} \mathrm{O} / \mathrm{CaO}$-ZnO to obtain a model of the heterogeneous reaction rate equation. The kinetic studies include prediction of the reaction mechanism in accordance with the experimental data through analysis of the dependence of changes in the rate of reaction on changes in each reactant and the formulation of the reaction rate law model. The obtained reaction rate equation can be used for reactor design. The results showed that the mechanism of the predicted reaction rate follows the Eley-Rideal mechanism, where methanol adsorbed on the catalyst surface reacts with triglycerides (soybean oil) which is in the liquid phase to produce biodiesel (fatty acid methyl ester) and glycerol. The obtained reaction rate model can be used for the reactor design, so that the relationship between the catalyst weight needed and the conversion of triglycerides to biodiesel and the calculation of the required reactor volume can be conducted.
\end{abstract}

Keywords: kinetics of transesterification reaction; soybean oil; biodiesel; $\mathrm{K}_{2} \mathrm{O} / \mathrm{CaO}-\mathrm{ZnO}$ catalyst; fluidized CSTR reactor

\section{Pendahuluan}

Biodiesel adalah salah satu sumber energi alternatif populer karena merupakan bahan bakar

\footnotetext{
${ }^{*}$ Penulis Korespondensi.

E-mail: istadi@che.undip.ac.id
}

yang biodegradable dan terbarukan, bersifat nontoksik, serta menghasilkan emisi yang lebih rendah dari CO. Proses transesterifikasi untuk menghasilkan biodiesel telah diteliti dari berbagai bahan minyak nabati seperti minyak sawit (Wong $d k k$., 2015), minyak biji jarak (Sanchez $d k k$., 2015), minyak rapeseed (Wang dkk., 2013), dan minyak kedelai (Lu 


\section{TEKNIK, 40 (3), 2019, 137}

$d k k ., 2015)$. Reaksi transesterifikasi dilakukan pada suhu yang dekat dengan titik didih metanol (60-70 ${ }^{\circ} \mathrm{C}$ ) pada tekanan atmosfer (Ramadhas $d k k$., 2005). Reaksi transesterifikasi pembuatan biodiesel (Knothe $d k k ., 2005)$ terlihat pada Persamaan 1.

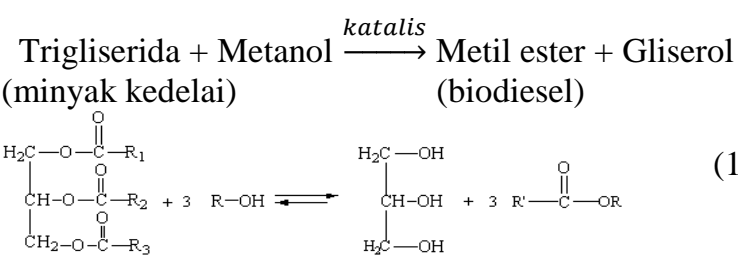

Penggunaan katalis basa heterogen pada proses transesterifikasi menjadi lebih ramah lingkungan, tidak menghasilkan sabun pada reaksi netralisasi asam lemak bebas sehingga menyederhanakan proses pemisahan dan pemurniannya, proses bersifat kontinyu, dan meningkatkan nilai ekonomi produksi biodiesel (Meher $d k k .$, 2006; Lotero, 2004; Fukuda $d k k$., 2001; Noureddini \& Zhu, 1997). CaO tercatat sebagai katalis transesterifikasi basa heterogen aktif karena sifat basa yang kuat, kelarutan rendah, dan mudah perlakuannya (Kouzu \& Hidaka, 2012; Boey dkk., 2011). Katalis $\mathrm{ZnO}$ dipakai pada banyak reaksi katalitik, murah, komersial, dapat digunakan kembali, juga sebagai penyangga katalis (Islam $d k k$., 2013; Karim $d k k$., 2008). Modifikasi $\mathrm{CaO}$ dengan $\mathrm{ZnO}$ pada transesterifikasi minyak sawit menghasilkan konversi FAME (fatty acid methyl ester/biodiesel) yang lebih tinggi mencapai hingga 94\% (Ngamcharussrivichai $d k k ., 2008)$.

Kombinasi $\mathrm{CaO}-\mathrm{ZnO}$ diprediksi dapat meningkatkan luas permukaan dan mengurangi leaching kandungan logamnya, walaupun dapat menurunkan kebasaan dan kekuatan mekanik katalis. Penambahan $\mathrm{K}_{2} \mathrm{O}$ yang diimpregnasi pada katalis $\mathrm{CaO}-\mathrm{ZnO}$ dapat meningkatkan kembali tingkat kebasaan, serta kekuatan mekanik dimana $\mathrm{K}_{2} \mathrm{O}$ dapat berperan sebagai binding agent.

Pendekatan kinetika penelitian ini berbeda dengan peneliti sebelumnya yang kebanyakan merumuskan kinetika kecepatan reaksi berdasarkan hasil pengamatan eksperimen secara empiris menggunakan asumsi model kinetika reaksi katalisis yang terlalu sederhana (misalnya: simple dan Power Law) (Masduki dkk., 2013; Sidabuntar dkk., 2013; Buchori \& Sasongko, 2012; Sari dkk., 2011; Aziz, 2007; Utami $d k k$., 2007). Penelitian sebelumnya tidak mengkaji prediksi mekanisme reaksi yang terjadi. Penelitian kajian perumusan kinetika reaksi pada transesterifikasi minyak kedelai menjadi biodiesel menggunakan katalis padat (heterogen) yang didasarkan pada prediksi mekanisme reaksi dari data eksperimen menjadi sangat penting.

Oleh karena itu, penelitian ini dilakukan untuk mengkaji kinetika reaksi transesterifikasi minyak kedelai menjadi biodiesel menggunakan katalis padat $\mathrm{K}_{2} \mathrm{O} / \mathrm{CaO}-\mathrm{ZnO}$ untuk mendapatkan model persamaan laju reaksi heterogen. Kajian kinetika penelitian ini meliputi: prediksi mekanisme yang sesuai dengan data eksperimen melalui analisis perubahan laju reaksi terhadap perubahan masing-masing reaktan dan perumusan persamaan akhir laju reaksi. Persamaan laju reaksi yang dihasilkan dapat dipakai pada desain perancangan reaktor.

\section{Bahan dan Metode}

2.1 Pembuatan Katalis

Proses diawali dengan membuat katalis $\mathrm{CaO}$ $\mathrm{ZnO}$ dengan perbandingan berat $\mathrm{Ca} / \mathrm{Zn} \quad 1: 1$ menggunakan metode kopresipitasi. $\mathrm{Ca}\left(\mathrm{NO}_{3}\right)_{2}$ (Merck, 99\%) dilarutkan dalam akuades hingga konsentrasi $1 \mathrm{M}$, kemudian dicampur dengan $\mathrm{Zn}\left(\mathrm{NO}_{3}\right)_{2}$ (Merck, 99\%) yang juga dilarutkan dalam akuades dengan konsentrasi $1 \mathrm{M}$. Sementara itu, $\mathrm{Na}_{2} \mathrm{CO}_{3}$ (Merck, 99\%) yang dilarutkan pada akuades dengan konsentrasi $2 \mathrm{M}$ diteteskan sedikit demi sedikit pada campuran sebelumnya dan diaduk cepat sampai terbentuk gel putih. Selanjutnya $\mathrm{pH}$ diatur hingga 10 dengan menambahkan larutan $\mathrm{NaOH}$ (Merck 99\%). Larutan disaring dan dicuci dengan akuades hingga bebas basa. Sisa gel dikeringkan dengan oven (Memmert) bersuhu $110{ }^{\circ} \mathrm{C}$ selama semalam. Langkah selanjutnya adalah mengkalsinasi katalis tersebut di dalam furnace elektrik (Ney Vulcan 3-550) pada suhu $800{ }^{\circ} \mathrm{C}$ selama 3 jam, sehingga dihasilkan butiran padat katalis $\mathrm{CaO}-\mathrm{ZnO}$. Selanjutnya dengan metode impregnasi, padatan katalis $\mathrm{CaO}-\mathrm{ZnO}$ tersebut dimasukkan ke dalam campuran $\mathrm{KNO}_{3}$ (Merck 99\%) yang dilarutkan dengan konsentrasi $1 \mathrm{M}$ selama 1 jam dan diaduk. Campuran tersebut kemudian dikeringkan di dalam oven bersuhu $110{ }^{\circ} \mathrm{C}$ selama semalam. Selanjutnya katalis yang dihasilkan dikalsinasi di dalam furnace elektrik pada suhu $300{ }^{\circ} \mathrm{C}$ selama 5 jam, sehingga dihasilkan katalis padat $\mathrm{K}_{2} \mathrm{O} / \mathrm{CaO}-\mathrm{ZnO}$.

\subsection{Pengujian Katalis untuk Reaksi Transesterifikasi \\ Gambar 1 menunjukkan rangkaian alat reaksi} transesterifikasi untuk pengujian katalis dalam reaktor fluidized CSTR, yang terdiri dari labu leher tiga (1), yang dilengkapi dengan pengaduk (8), kondenser refluks (6), elbow (7), adapter (10) dan termometer (3). Pengaduk digerakkan oleh motor penggerak (4) dengan pengatur motor controller (5). Rangkaian diletakkan pada pemanas mantel (M-Top Heating Mantle MS-E) (2) yang berada di atas rangka portable (11) yang dilengkapi dengan statif dan klem (9). Selang air pendingin menghubungkan ujung bawah dan atas kondenser refluks.

Minyak kedelai, metanol, dan katalis 5\% $\mathrm{K}_{2} \mathrm{O} / \mathrm{CaO}-\mathrm{ZnO}$ dimasukkan ke dalam labu leher tiga. Perbandingan mol umpan trigliserida (A) terhadap metanol (B) bervariasi dari 1:2 hingga 1:25. Volume total reaktan tetap $400 \mathrm{~mL}$. Larutan dipanaskan sampai suhu stabil pada $60{ }^{\circ} \mathrm{C}$ (di bawah titik didih metanol $64,7{ }^{\circ} \mathrm{C}$ ) dan diaduk selama 3 jam. Produk didinginkan dan dipisahkan pada corong pemisah, 
didiamkan semalam hingga terbentuk 3 lapisan, yaitu: lapisan atas metanol sisa, lapisan tengah metil ester, dan lapisan bawah sisa minyak kedelai, gliserol, dan katalis. Produk metil ester dianalisis menggunakan GC-MS (Shimadzu QP2010S, dengan kolom DB-1).

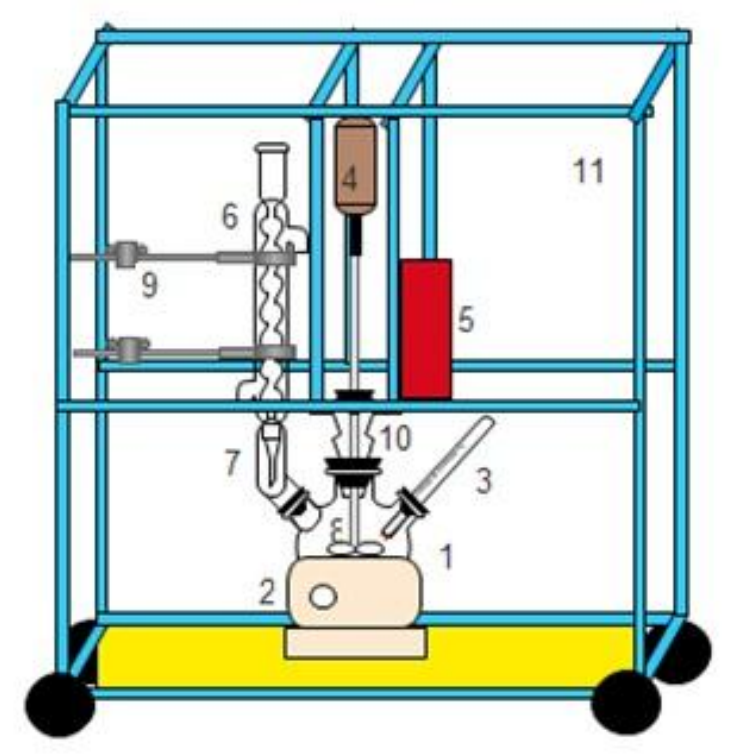

Gambar 1. Rangkaian alat transesterifikasi

\subsection{Kajian Kinetika Reaksi}

Kajian kinetika reaksi meliputi: (1) analisis perubahan laju reaksi terhadap perubahan perbandingan masing-masing reaktan; (2) prediksi mekanisme reaksi yang sesuai dengan data eksperimen; dan (3) perumusan persamaan akhir laju reaksi.

Pada reaktor batch heterogen, perhitungan laju reaksi eksperimen mengikuti Persamaan 2.

$$
-r_{A \exp }=\frac{N_{p}}{W \cdot d t}=\frac{\rho . V}{M r \cdot W \cdot d t}
$$

dimana $-r_{\mathrm{A}}$ exp adalah laju reaksi hasil data eksperimen (mol/gcat.s), $N_{\mathrm{P}}$ adalah mol produk (mol), $W$ merupakan berat katalis (gcat), dan $d t$ adalah rentang waktu reaksi (s).

Persamaan laju reaksi yang dihasilkan dapat dipakai pada desain perancangan reaktor. Dalam tahapan ini, hubungan antara berat katalis yang dibutuhkan oleh reaksi dan konversi trigliserida menjadi biodiesel dapat diketahui sehingga jumlah kebutuhan katalis untuk mencapai tingkat konversi tertentu dapat diprediksi. Lebih jauh lagi, perhitungan volume reaktor yang dibutuhkan untuk mencapai konversi reaksi tersebut dapat dilakukan.

\section{Hasil dan Pembahasan}

Konsentrasi produk dipantau untuk kondisi umpan yang berbeda berdasarkan analisis perubahan perbandingan reaktan terhadap perubahan laju reaksi kimia pada saat reaksi sudah berjalan secara tunak (steady state).
Tabel 1. Data perubahan kecepatan reaksi $\left(-r_{\mathrm{A}}\right)$ terhadap konsentrasi metanol (B) $\left(-r_{\mathrm{A} \text { exp }}=-r_{\mathrm{A}}\right.$ hasil data eksperimen) $\left(C_{\mathrm{A}}\right.$ : konsentrasi trigliserida; $C_{\mathrm{B}}$ : konsentrasi metanol; $C_{\mathrm{C}}$ : konsentrasi metil ester; $C_{\mathrm{D}}$ : konsentrasi gliserol)

\begin{tabular}{|c|c|c|c|c|c|c|c|}
\hline Run & $\begin{array}{r}\mathrm{Ra} \\
\mathrm{m} \\
\mathrm{A}\end{array}$ & $\begin{array}{l}\text { sio } \\
\text { ol } \\
\text { B }\end{array}$ & $\begin{array}{c}C_{\mathrm{A}} \\
(\mathrm{mol} / \\
\mathrm{L})\end{array}$ & $\begin{array}{c}C_{\mathrm{B}} \\
(\mathrm{mol} / \\
\mathrm{L})\end{array}$ & $\begin{array}{c}C_{\mathrm{C}} \\
(\mathrm{mol} / \\
\mathrm{L})\end{array}$ & $\begin{array}{c}C_{\mathrm{D}} \\
(\mathrm{mol} / \\
\mathrm{L})\end{array}$ & $\begin{array}{l}-r_{\mathrm{A} \exp } \\
\text { (mol/ } \\
\text { gcat.s) }\end{array}$ \\
\hline 1 & 1 & 25 & 0,50 & 12,52 & 1,48 & 4,37 & $3,68 \times 10^{-6}$ \\
\hline 2 & 1 & 15 & 0,63 & 9,42 & 1,47 & 4,96 & $3,65 \times 10^{-6}$ \\
\hline 3 & 1 & 10 & 0,72 & 7,20 & 1,47 & 5,83 & $3,64 \times 10^{-6}$ \\
\hline 4 & 1 & 6 & 0,81 & 4,89 & 1,45 & 5,99 & $3,57 \times 10^{-6}$ \\
\hline 5 & 1 & 3 & 0,90 & 2,71 & 1,44 & 6,13 & $3,54 \times 10^{-6}$ \\
\hline 6 & 1 & 2 & 0,94 & 1,88 & 1,41 & 5,99 & $3,48 \times 10^{-6}$ \\
\hline
\end{tabular}

Tabel 1 menunjukkan bahwa pada percobaan nomor 4, 3, dan 2 dengan kenaikan konsentrasi metanol sampai dengan ekses, kecepatan reaksi yang dihasilkan meningkat. Pada percobaan nomor 2 dan 1 jika konsentrasi metanol ditingkatkan secara ekstrim, kecepatan reaksi juga meningkat. Hal ini menunjukkan kesesuaian antara konsentrasi awal reaktan dengan kecepatan reaksi pembentukan produk, sehingga dapat dinyatakan bahwa metanol teradsorpsi pada permukaan katalis. Sesuai dengan pernyataan Fogler (2016), apabila kecepatan reaksi berbanding lurus dengan peningkatan konsentrasi reaktan maka reaktan tersebut teradsopi pada permukaan katalis.

Tabel 2. Data perubahan kecepatan reaksi $\left(-r_{\mathrm{A}}\right)$ terhadap konsentrasi trigliserida (A). $\left(-r_{\mathrm{A} \text { exp }}=-r_{\mathrm{A}}\right.$ hasil data eksperimen) $\left(C_{\mathrm{A}}\right.$ : konsentrasi trigliserida; $C_{\mathrm{B}}$ : konsentrasi metanol; $C_{\mathrm{C}}$ : konsentrasi metil ester; $C_{\mathrm{D}}$ : konsentrasi gliserol)

\begin{tabular}{|c|c|c|c|c|c|c|c|}
\hline \multirow[t]{2}{*}{ Run } & \multicolumn{2}{|c|}{$\begin{array}{c}\text { Rasio } \\
\text { mol }\end{array}$} & \multirow{2}{*}{$\begin{array}{c}C_{\mathrm{A}} \\
(\mathrm{mol} / \\
\mathrm{L})\end{array}$} & \multirow{2}{*}{$\begin{array}{c}C_{\mathrm{B}} \\
(\mathrm{mol} / \\
\mathrm{L})\end{array}$} & \multirow{2}{*}{$\begin{array}{c}C_{\mathrm{C}} \\
(\mathrm{mol} / \\
\mathrm{L})\end{array}$} & \multirow{2}{*}{$\begin{array}{c}C_{\mathrm{D}} \\
(\mathrm{mol} / \\
\mathrm{L})\end{array}$} & \multirow{2}{*}{$\begin{array}{c}-r_{\mathrm{A} \text { exp }}, \\
(\mathrm{mol} / \\
\text { gcat.s })\end{array}$} \\
\hline & A & $\mathrm{B}$ & & & & & \\
\hline 1 & 0,24 & 6 & 0,50 & 12,52 & 1,48 & 4,37 & $3,68 \times 10^{-6}$ \\
\hline 2 & 0,6 & 6 & 0,63 & 9,42 & 1,47 & 4,96 & $3,65 \times 10^{-6}$ \\
\hline 3 & 0,4 & 6 & 0,72 & 7,20 & 1,47 & 5,83 & $3,64 \times 10^{-6}$ \\
\hline 4 & 1 & 6 & 0,81 & 4,89 & 1,45 & 5,99 & $3,57 \times 10^{-6}$ \\
\hline 5 & 2 & 6 & 0,90 & 2,71 & 1,44 & 6,13 & $3,54 \times 10^{-6}$ \\
\hline 6 & 3 & 6 & 0,94 & 1,88 & 1,41 & 5,99 & $3,48 \times 10^{-6}$ \\
\hline
\end{tabular}

Perlakuan yang sama juga dilakukan terhadap reaktan trigliserida. Pada Tabel 2 percobaan nomor 4 , 5, dan 6, konsentrasi trigliserida meningkat tetapi kecepatan reaksi menurun. Kecenderungan yang berkebalikan ini menunjukkan bahwa trigliserida tidak teradsorpsi pada permukaan katalis. Sebagaimana dinyatakan oleh Fogler (2016), apabila kecepatan reaksi berbanding terbalik dengan peningkatan konsentrasi reaktan maka reaktan tersebut tidak teradsorpsi pada permukaan katalis.

Berdasarkan hasil analisis kecepatan reaksi terhadap konsentrasi reaktan, salah satu reaktan, yaitu metanol, teradsorpsi pada permukaan katalis sedangkan treaktan yang lainnya, trigliserida, tidak 
teradsorpsi pada permukaan katalis. Hal ini menunjukkan bahwa mekanisme reaksi katalitik yang terjadi mengikuti mekanisme Eley-Rideal dimana salah satu reaktan teradsorpsi pada permukaan katalis dan reaktan yang lainnya berada pada fasa bulk-nya (Fogler, 2016).

Mekanisme reaksi yang mungkin terjadi adalah metanol (B) teradsorpsi pada permukaan katalis bereaksi dengan trigliserida (A) pada fase cairnya menghasilkan biodiesel fatty acid methyl ester (C) dan gliserol (D) yang salah satunya teradsorpsi pada permukaan katalis. Prediksi mekanisme reaksi permukaan yang mungkin terjadi adalah:

- A fase cair + B teradsorp $\rightleftarrows$ C teradsorp + D fase cair (tipe 1)

- A fase cair + B teradsorp $\rightleftarrows \mathrm{C}$ fase cair $+\mathrm{D}$ teradsorp (tipe 2)

Model kinetika reaksi katalitiknya dapat disusun sebagai Persamaan 3 hingga 8.

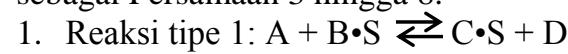

a. Adsorpsi B

$$
-r_{A}=\frac{k_{B}\left(C_{B}-\frac{C_{C} C_{D}}{K_{B} K_{C} K_{S} C_{A}}\right)}{\frac{C_{C} C_{D}}{K_{C} K_{S} C_{A}}+\frac{C_{C}}{K_{C}}+1}
$$

b. Reaksi permukaan

$$
-r_{A}=\frac{k_{S}\left(K_{B} C_{A} C_{B}-\frac{C_{C} C_{D}}{K_{C} K_{S}}\right)}{K_{B} C_{B}+\frac{C_{C}}{K_{C}}+1}
$$

c. Desorpsi C

$$
-r_{A}=\frac{k_{C}\left(\frac{K_{B} K_{S} C_{A} C_{B}}{C_{D}}-\frac{C_{C}}{K_{C}}\right)}{K_{B} C_{B}+\frac{K_{B} K_{S} C_{A} C_{B}}{C_{D}}+1}
$$

2. Reaksi tipe $2: \mathrm{A}+\mathrm{B} \cdot \mathrm{S} \rightleftarrows \mathrm{C}+\mathrm{D} \cdot \mathrm{S}$

a. Adsorpsi B

$$
-r_{A}=\frac{k_{B}\left(C_{B}-\frac{C_{C} C_{D}}{K_{B} K_{D} K_{S} C_{A}}\right)}{\frac{C_{C} C_{D}}{K_{D} K_{S} C_{A}}+\frac{C_{D}}{K_{D}}+1}
$$

b. Reaksi permukaan

$$
-r_{A}=\frac{k_{S}\left(K_{B} C_{A} C_{B}-\frac{C_{C} C_{D}}{K_{D} K_{S}}\right)}{K_{B} C_{B}+\frac{C_{D}}{K_{D}}+1}
$$

c. Desorpsi D

$$
-r_{A}=\frac{k_{D}\left(\frac{K_{B} K_{S} C_{A} C_{B}}{C_{C}}-\frac{C_{D}}{K_{D}}\right)}{K_{B} C_{B}+\frac{K_{B} K_{S} C_{A} C_{B}}{C_{C}}+1}
$$

Dimana $r_{\mathrm{A}}$ adalah laju reaksi (mol/gcat.s). Sedangkan $k_{\mathrm{B}}, k_{\mathrm{s}}, k_{\mathrm{C}}$, dan $k_{\mathrm{D}}$ secara berurutan adalah konstanta laju adsorbsi B, konstanta laju raksi permukaan, konstanta laju desorbsi $\mathrm{C}$ dan $\mathrm{D}$ dengan satuan $\mathrm{s}^{-1}$. $K_{\mathrm{B}}, K_{\mathrm{S}}, K_{\mathrm{C}}$, dan $K_{\mathrm{D}}$ secara berurutan adalah konstanta kesetimbangan adsorbsi B, konstanta kesetimbangan reaksi permukaan, serta konstanta kesetimbangan desorpsi C dan D. Keempat konstanta tersebut tidak memiliki satuan karena merupakan perbandingan. Sedangkan $C_{\mathrm{A}}, C_{\mathrm{B}}, C_{\mathrm{C}}$, dan $C_{\mathrm{D}}$ secara berurutan merupakan konsentrasi A (trigliserida), konsentrasi B (methanol), konsentrasi C (metil ester) dan konsentrasi D (gliserol) dengan satuan mol/gcat.

Berdasarkan analisis kesesuaian antara data eksperimen dengan model kecepatan reaksi yang mungkin maka dapat disimpulkan bahwa persamaan kecepatan reaksi $-r_{\mathrm{A}}$ terlihat pada Persamaan 9.

$-r_{A}=\frac{0,0002\left(0,4987 \frac{C_{A} C_{B}}{C_{D}}-0,1181 C_{C}\right)}{0,0263 C_{B}+0,4987 \frac{C_{A} C_{B}}{C_{D}}+1}$

dengan nilai koefisien determinasi $\mathrm{R}^{2}$ sebesar 0,9628 untuk katalis padat $5 \% \mathrm{~K}_{2} \mathrm{O} / \mathrm{CaO}-\mathrm{ZnO}$ pada reaksi transesterifikasi trigliserida dan metanol menghasilkan biodiesel/fatty acid methyl ester pada reaktor fluidized CSTR.

Beberapa peneliti telah melakukan kajian kinetika reaksi transesterifikasi minyak nabati menjadi biodiesel manggunakan katalis homogen (katalis fase cair) (Masduki $d k k ., 2013$; Sidabuntar dkk., 2013; Buchori \& Sasongko, 2012; Aziz, 2007; Utami $d k k ., 2007)$. Akan tetapi, kajian kinetika reaksi yang dilakukan oleh peneliti sebelumnya masih sangat sederhana dibandingkan dengan kajian yang dilakukan pada studi ini. Para peneliti sebelumnya hanya mengasumsikan bahwa reaksi yang terjadi mengikuti kinetika reaksi irreversible pseudo order satu terhadap trigliserida (Sidabuntar $d k k$., 2013; Utami $d k k ., 2007)$ dan irreversible pseudo order dua terhadap trigliserida (Aziz, 2007) dengan mengasumsikan ekses alkohol. Kajian yang lebih kompleks dilakukan oleh Buchori \& Sasongko (2012) dengan mengasumsikan bahwa mekanisme reaksi yang terjadi adalah reaksi reversible elementer. Kajian kinetika reaksi transesterifikasi minyak nabati menggunakan katalis padat / heterogen juga telah dilakukan oleh beberapa peneliti (Masduki $d k k$., 2013; Sari $d k k$., 2011). Akan tetapi, kajian yang dilakukan oleh peneliti sebelumnya masih sederhana yaitu dengan mengasumsikan bahwa sistem reaksi adalah pseudo-homogen dan mekanisme reaksi mengikuti rekasi pseudo order satu. Peneliti sebelumnya masih belum bisa menjelaskan mekanisme reaksi yang terjadi untuk sistem heterogen seperti yang dilakukan pada studi ini.

Persamaan laju reaksi yang dihasilkan (Persamaan 7) dapat digunakan untuk perhitungan berat katalis yang dibutuhkan pada reaktor fluidized CSTR yang diperlukan untuk mencapai konversi tertentu mengikuti persamaan desain (Persamaan 10) (Fogler, 2016).

In - Out + Generation $=$ Accumulation

$F_{\mathrm{T} 0}-F_{\mathrm{T}}+r_{\mathrm{A}} \cdot W=0 \quad$ (Steady state)

$W=\frac{F_{\mathrm{T} 0}-F_{\mathrm{T}}}{-r_{\mathrm{A}}}$ 


$$
\begin{aligned}
& W=\frac{F_{\mathrm{T} 0} \cdot X}{-r_{\mathrm{A}}} \\
& V=\frac{W}{\rho_{\mathrm{b}}}
\end{aligned}
$$

Persamaan (9) menunjukkan hubungan antara berat katalis $(W)$, laju alir umpan $\left(F_{\mathrm{T} 0}\right)$, dan konversi $(X)$ trigliserida. Sedangkan persamaan (10) menunjukkan perbandingan antara volume reaktor dan berat katalis yang tetap.

Jika diasumsikan bulk density $\left(\rho_{\mathrm{b}}\right)$ campuran katalis di dalam reaktor fluidized CSTR adalah 0,5 $\mathrm{g} / \mathrm{mL}$, dengan berat katalis $5 \mathrm{~g}$ untuk mencapai konversi 99\%, maka volume reaktor yang dibutuhkan adalah $10 \mathrm{~mL}$. Lebih detil tentang perhitungan volume reaktor yang dibutuhkan ditunjukkan pada Tabel 3.

Tabel 3. Data konversi trigliserida menjadi FAME $(X)$ sebagai fungsi berat katalis $(W)$ dan prediksi volume reaktor fluidized CSTR

\begin{tabular}{cccccccc}
\hline \multirow{2}{*}{ Run } & $\begin{array}{c}\text { Rasio } \\
\text { mol }\end{array}$ & \begin{tabular}{c}
$F_{\mathrm{T} 0}$ \\
$(\mathrm{~mol}$ \\
\cline { 2 - 7 }
\end{tabular} & $\begin{array}{c}-r_{\mathrm{A} \text { exp }} \\
\text { minyak/s) }\end{array}$ & $\begin{array}{c}\text { gcat.s }) \\
\text { gcol/ }\end{array}$ & $X$ & $\begin{array}{c}W \\
(\mathrm{gcat})\end{array}$ & $\begin{array}{c}\text { Volume } \\
\text { Reaktor } \\
(\mathrm{mL})\end{array}$ \\
\hline 1 & 1 & 25 & $1,86 \times 10^{-5}$ & $3,68 \times 10^{-6}$ & 0,99 & 5 & 10 \\
2 & 1 & 15 & $2,33 \times 10^{-5}$ & $3,65 \times 10^{-6}$ & 0,78 & 5 & 10 \\
3 & 1 & 10 & $2,67 \times 10^{-5}$ & $3,64 \times 10^{-6}$ & 0,68 & 5 & 10 \\
4 & 1 & 6 & $3,02 \times 10^{-5}$ & $3,57 \times 10^{-6}$ & 0,59 & 5 & 10 \\
5 & 1 & 3 & $3,35 \times 10^{-5}$ & $3,54 \times 10^{-6}$ & 0,53 & 5 & 10 \\
6 & 1 & 2 & $3,48 \times 10^{-5}$ & $3,48 \times 10^{-6}$ & 0,50 & 5 & 10 \\
\hline
\end{tabular}

Pada perbandingan rasio mol trigliserida/metanol dan $-r_{\mathrm{A}}$ yg tetap, untuk mencapai konversi tertentu, maka dapat diprediksi berat katalis dan laju alir umpan pada volume reaktor yang lebih besar. Tabel 4 menunjukkan prediksi berat katalis dan laju alir umpan, dengan hasil akhir konversi trigliserida mencapai 99\%, pada rasio mol trigliserida/metanol 1:25.

Tabel 4. Prediksi berat katalis $(W)$ dan laju alir umpan $\left(F_{\mathrm{T} 0}\right)$ pada volume reaktor fluidized CSTR yang lebih besar, dengan konversi dan rasio mol yang tetap.

\begin{tabular}{cccccc}
\hline $\begin{array}{c}-r_{\mathrm{A} \exp } \\
(\mathrm{mol} /\end{array}$ & $X$ & $\begin{array}{c}\rho_{\mathrm{b}} \\
(\mathrm{g} / \mathrm{mL})\end{array}$ & $\begin{array}{c}\text { Volume } \\
\text { reaktor } \\
\text { gcat.s })\end{array}$ & $\begin{array}{c}W \\
(\mathrm{~mL})\end{array}$ & $\begin{array}{c}F_{\mathrm{T} 0} \\
(\mathrm{~mol}) \\
\text { minyak/s })\end{array}$ \\
\hline $3,68 \times 10^{-6}$ & 0,99 & 0,5 & 10 & 5 & $1,86 \times 10^{-5}$ \\
$3,68 \times 10^{-6}$ & 0,99 & 0,5 & 1000 & 500 & $1,86 \times 10^{-3}$ \\
$3,68 \times 10^{-6}$ & 0,99 & 0,5 & 100000 & 50000 & 0,186 \\
\hline
\end{tabular}

\section{Kesimpulan}

Mekanisme reaksi yang terjadi pada reaksi transesterifikasi trigliserida dan metanol menjadi biodiesel atau fatty acid methyl ester menggunakan katalis padat ramah lingkungan $\mathrm{K}_{2} \mathrm{O} / \mathrm{CaO}-\mathrm{ZnO}$ adalah mengikuti mekanisme Eley-Rideal. Methanol teradsorpsi di permukaan katalis yang bereaksi dengan trigliserida (minyak kedelai) pada fase cairnya menghasilkan fatty acid methyl ester dan gliserol. Persamaan laju reaksi yang sesuai dengan mekanisme reaksi dapat digunakan dalam perancangan reaktor, sehingga hubungan antara berat katalis yang dibutuhkan dengan konversi trigliserida menjadi biodiesel dan prediksi perhitungan volume reaktor yang dibutuhkan dapat dilakukan.

\section{Ucapan terima kasih}

Terima kasih disampaikan kepada Departemen Teknik Kimia Fakultas Teknik Undip yang telah memfasilitasi penelitian ini, juga kepada rekan peneliti Setiarto Pratigto yang telah membantu dalam eksperimen laboratorium.

\section{Daftar Pustaka}

Aziz, I. (2007). Kinetika reaksi transesterifikasi minyak goreng bekas. Jurnal Kimia Valensi, 1(1), 19-23.

Boey, P. L., Maniam, G. P., Hamid, S. A. (2011). Performance of calcium oxide as a heterogeneous catalyst in biodiesel production: A review. Chemical Engineering Journal, 168, 15-22.

Buchori, L., Sasongko, S.B. (2012). Kinetika Transesterifikasi Biodiesel Jarak Pagar. Teknik, 33(2), 52-57.

Fogler, H. S. (2016). Elements of Chemical Reaction Engineering. 5th Ed. Houston: Prentice Hall.

Fukuda, H., Kondo, A., Noda, H. (2001). Biodiesel Fuel Production by Transesterification of Oils. Journal of Bioscience and Bioengineering, 92 (5), 405-416.

Islam, A., Taufiq Yap, Y. H., Chu, C. M., Chan, E. S., Ravindra, P. (2013). Studies on design of heterogeneous catalysts for biodiesel production. Process Safety and Enviromental Protection, 91, 131-144.

Karim, A.M., Conant, T., Datye, A.K. (2008). Controlling $\mathrm{ZnO}$ morphology for improved methanol steam reforming reactivity. Physical Chemistry Chemical Physics, 10(36), 5584-5590.

Knothe, G., Gerpen, J.V., Krahl, J. (2005). The Biodiesel Handbook. Illinois: AOCS Press.

Kouzu, M., Hidaka, J.S. (2012). Transesterification of vegetable oil into biodiesel catalyzed by CaO: A review. Fuel, 93, 1-12.

Lotero, E. (2004). Synthesis of biodiesel via acid catalysis. Journal South Carolina, 44(14), 5353-5363.

Lu, Y., Zhang, Z., Xu, Y., Liu, Q., Qian, G. (2015). $\mathrm{CaFeAl}$ mixed oxide derived heterogeneous catalysts for transesterification of soybean oil to biodiesel. Bioresource Technology, 190, 438-441.

Masduki, M., Sutijan, S., Budiman, A. (2013). Kinetika Reaksi Esterifikasi Palm Fatty Acid Distilate (PFAD) menjadi Biodiesel dengan 


\section{TEKNIK, 40 (3), 2019, 141}

Katalis Zeolit-Zirkonia Tersulfatasi. Jurnal Rekayasa Proses, 7(2), 59-64.

Meher, L. C., Vidya Sagar, D., Naik, S. N. (2006). Technical aspects of biodiesel production by transesterification - a review. Renewable and Sustainable Energy Reviews, 10, 248-268.

Ngamcharussrivichai, C., Totarat, P., Bunyakiat, K. (2008). Ca and $\mathrm{Zn}$ mixed oxide as a heterogeneous base catalyst for transesterification of palm kernel oil. Applied Catalysis A: General, 341, 77-85.

Noureddini, H., Zhu, D. (1997). Kinetics of transesterification of soybean oil. JAOCS, 74(11), 1457-1463.

Ramadhas, A S., Jayaraj, S., Muraleedharan, C. (2005). Biodiesel production from high FFA rubber seed oil. Fuel, 84, 335-340.

Sanchez, N., Sanchez, R., Encinar, J.M., Gonzalez, J.F., Martinez, G. (2015). Complete analysis of castor oil methanolysis to obtain biodiesel. Fuel, 147, 95-99.

Sari, T.I., Said, M., Sari, A.K. (2011). Katalis Basa Heterogen Campuran $\mathrm{CaO} \& \mathrm{SrO}$ Pada Reaksi Transesterifikasi Minyak Kelapa
Sawit. Dalam Prosiding Seminar Nasional AVoER ke-3, Palembang, Indonesia: Fakultas Teknik Universitas Sriwijaya, 482493.

Sidabutar, E.D.C., Faniudin, M.N., Said, M. (2013). Pengaruh rasio reaktan dan jumlah katalis terhadap konversi minyak jagung menjadi metil ester. Jurnal Teknik Kimia, 19(1), 4049.

Utami, T.S., Arbianti, R., Nurhasman, D. (2007). Kinetika reaksi transesterifikasi CPO terhadap produk metil palmitat dalam reaktor tumpak. Seminar Nasional Fundamental dan Aplikasi Teknik Kimia 2007. Surabaya, Indonesia: Jurusan Teknik Kimia FTI - ITS.

Wang, B., Li, S., Tian, S., Feng, R., Meng, Y. (2013). A new solid base catalyst for the transesterification of rapeseed oil to biodiesel with methanol. Fuel, 104, 698-703.

Wong, Y.C., Tan, Y.P., Taufiq Yap, Y.H., Ramli, I., Tee, H. (2015). Biodiesel production via transesterification of palm oil by using $\mathrm{CaO}$ $\mathrm{CeO}_{2}$ mixed oxide catalyst. Fuel, 162, 288293. 